\title{
The American Puritan Jeremiad Tradition in
}

\section{The Love Song of J. Alfred Prufrock}

\author{
Ting-ting Zhou \\ College of International Studies, Southwest University, China
}

Received: 02-09-2014

Accepted: 22-10- 2014

Published: 31-10- 2014

doi:10.7575/aiac.ijclts.v.2n.4p.50

URL: http://dx.doi.org/10.7575/aiac.ijclts.v.2n.4p.50

\begin{abstract}
In The Love Song of J. Alfred Prufrock, T.S. Eliot employs an admonishing style and represents the Puritan errand to indicate the influence of the American Puritan jeremiad tradition. Like a prophet howling in the wilderness; Eliot denounces the moral corruption of the New England city Boston and the spiritual paralysis of its inhabitants. Besides, he goes back to the Bay Colony during the $17^{\text {th }}$ century and ironically represents the Puritan errand into the wilderness. Eliot's attitude towards the Puritan errand is ambivalent. Influenced by his family's sense of mission, Eliot is haunted by images which remind him of the Puritan errand. Meanwhile, he denies the errand by a satirical portrait of Prufrock, the modern incarnation of John the Baptist. The poem can be considered as an anti-jeremiad. The anti-jeremiad is not a rejection of the Puritan jeremiad but a variation of a same figural-symbolic outlook. Both jeremiads and anti-jeremiads are equal and opposite expressions of the symbol of America. The symbol sustains and restricts the imagination of Eliot, barring him from paths that led beyond the boundaries of American culture.
\end{abstract}

Keywords: Jeremiad, Anti-jeremiad, Prophet, Errand, Anxiety

\section{Introduction}

The Love Song of J. Alfred Prufrock, which was composed in 1910, is one of the most important poems of T.S. Eliot. When critics analyze the poem, they either focus on the character's psychological state or the poem's revelation of the decay of Western civilization. For example, Tony Pinkey thinks that "the world of J. Alfred Prufrock is clearly a paranoid-schizoid one, composed of shadows rather than solid things."(Pinkey, 1984, p.40) Elizabeth Drew believes that Prufrock retreats into "the world of despairing introspective day-dream" and mingles "self-pity and self-disgust". (Drew, 1949, p.34) Cleanth Brooks points out that " 'the love song' is not primarily about the plight of an individual person or a particular city but about the plight of an era and of Western civilization itself. "(Brooks, 1988, p.80)

It is a pity that critics ignore the poet's Puritan background. As a descendant of the Puritans, Eliot has a deep affiliation with the Puritan New England. Andrew Eliot, his first American ancestor, migrated in 1669 from the village of East Coker, Somerset County, England, to colonial Massachusetts. Although Eliot's grandparents reached Missouri in the 1830 s, the family carefully maintained its connection with New England. When Eliot was a child, he spent every summer in the house his father bought in Cape Ann, Massachusetts. He enrolled at Harvard University In 1906 and spent his formative years in Boston. The poem, composed just before Eliot left for Europe in 1910, is the sum of Eliot's New England experiences. With the modern New England city Boston as its setting, the poem denounces the moral decadence of the city and its people. It traces track to the Bay Colony during the $17^{\text {th }}$ century and ironically represents the Puritan errand into the wilderness.

The essay aims to show that the poem is influenced by the American Puritan jeremiad tradition. Considered as a mode of denunciation, the jeremiad was an ancient formulaic refrain in Europe. In the $17^{\text {th }}$ century, it was imported to Massachusetts from the Old world. Later, it was combined with the rhetoric of mission and became "America's first literary type".(Miller,1953, p.29) In the latter half of the $17^{\text {th }}$ century, New England became more and more secularized and commercialized. In 1679, under the leadership of Increase Mather, a synod met at Boston and made a report on why the land suffered. The ministers enumerated the land's enormities under twelve general heads:a decay of godliness, pride, heretics, sleep at sermons, the violation of sabbath, the decay of family government, contention, sins of sex and alcohol, telling lies, unwillingness to reform, destitute of civic spirit. (Miller,1956,p.8) The Puritan ministers felt worried about the moral decline of the society. They developed and standardized a special form of sermon. They "would take up some verse of Isaiah or Jeremiah, set up the doctrine that God avenges the iniquities of a chosen people, and then run down the twelve heads, merely bringing the list up to date by inserting the new and still more depraved practices an ingenious people kept on devising." (Miller,1956, p.8)

Despite its denunciation of the crimes of the Bay Colony, the Puritan jeremiad was characterized by its unswerving faith in the Puritan errand. The Puritans believed they were a peculiar people and their mission a peculiar one. Their churchstate was to be a model to the world of Reformed Christianity and a prefiguration of New Jerusalem to come. The Puritans acknowledged the declension of New England, but their cries of declension and doom were part of a strategy 
designed to revitalize the errand: "They believed God's punishments were corrective, not destructive. His vengeance was a sign of love, a father's rod used to improve the errant child. In short, their punishments confirmed their promise." (Bercovitch, 1978, p.8) The purpose of their jeremiads was to direct an imperiled people of God toward the fulfillment of their destiny, to guide them individually toward salvation, and collectively toward the American city of God. (Bercovitch, 1978, p.9)

The Puritan jeremiad persists throughout the $18^{\text {th }}$ and $19^{\text {th }}$ century in all forms of the literature and helps sustain a symbol of America through two hundred years of turbulence and change. Bercovitch points out that the ritual of the jeremiad bespeaks an "ideological consensus" and has played a major role in fashioning the myth of America which sustains and restricts the imagination of American writers. ( Bercovitch, 1978, p.176 )

\section{The Prophet Howling in the American Wilderness}

Eliot inherited from his family a Puritan conscience. His grandfather William Greenleaf Eliot was an Unitarian clergyman but his temper was more Calvinistic than Unitarian. He published Letters to Young men in Boston in 1854 to warn his grandson of the terrible temptations he must at his peril avoid. The roads to ruin include alcohol, violation of the lord's day, the sin of gambling, lust. ( Miller Jr. 2005, p.15 ) Charlotte, Eliot's mother, loved writing poetry but her strength is essentially that of a preacher. She wrote habitually of "the vision of the seer" and "the prophet's warning cry”. ( Gordon, 1977, p.5 ) Influenced by his grandfather and mother, Eliot had an acute moral consciousness. Like a prophet howling in the wilderness, Eliot denounces fiercely the corruption of the modern city Boston and its inhabitants.

Boston at the turn of the $20^{\text {th }}$ century was no longer "the city upon a hill" governed by the Puritan conscience but a society in decadence. The political and moral power of its oldest and most distinguished citizens had been displaced by great commercial corporations. The profit-first principle of the industrial age replaced Mosaic laws. The poem presents hell-like urban images. The city is shrouded in "yellow smoke" and "yellow fog"(Eliot, 1969, p.13) due to industrial pollution. "The dry pool" (Eliot, 1969, p.5) hints at spiritual dryness and a failure to resurrect. The inhabitants in the city are compared to "a patient etherized upon a table". (Eliot, 1969, p.13) From the perspective of the Puritan doctrine of original sin, "patient" is a metaphor for a sinner. The metaphorical meaning of "patient" indicates the moral decadence and spiritual paralysis of the urban inhabitants. The working-class residents in the "half-deserted streets" ( Eliot, 1969, p.13 ) lead a licentious and vulgar life. They indulge themselves in "one-night cheap hotels and sawdust restaurants with oyster-shells" ( Eliot, 1969, p.13) which hints at deadly sins of lust and gluttony. The upperclass women "in the room" are much like prostitutes. In biblical tradition, "prostitutes" are usually synonyms for heretics. Their bodies which smell of "perfume" and their "white and bare arms" (Eliot, 1969, p.15) are sensually attractive. They feign to talk about "Michelangelo" (Eliot, 1969, p.14) to show off their refined taste. However, in fact, they stealthily laugh at Prufrock's "bald spot in the middle of his hair", "thin hair" and "thin arms and legs". (Eliot, 1969, p.14)

Eliot feels distressed about the sins of the modern descendents of Puritans. Identified with the character Prufrock, he "wept and fasted, wept and prayed"(Eliot, 1969, p.15) to express his disquietude and persuades people to regret and reform. In biblical tradition, "weeping", "fast" and "praying" are rituals by which prophets communicate with God. For example, when Jerusalem was to be destroyed by God due to its corruption and betrayal, Jeremiah wept bitterly and mourned for the coming destruction of the city and the sufferings of its people.(Jeremiah 8:14-22) Before Jesus began his public ministry, he fasted in the desert for 40 days and endured the temptation by the Devil. (Matthew 4:1-11)When Daniel came to understand that the years for the desolation of Jerusalem was 70 in number, he implored God by prayer and requests to turn his raging anger away from the holy city. (Daniel 9:1-17) The rituals of "weeping", "fast" and "praying" allude to the ceremony of the humiliation day. In the Bay Colony in the $17^{\text {th }}$ century, when there were winds, storms, plagues, pests, smallpox, fires, etc, a day of humiliation would be appointed. On that day people were required to abstain from bodily labor, gather in their churches and listened to the ministers' jeremiads. The ministers denounced the iniquities of the people and warned that if they did not acknowledge their sins and promise reform, the punishment was forthcoming. Influenced by the ministers' admonition, the listeners wept, fasted and prayed to beg for God's forgiveness. By referring to the humiliation day, Eliot directs a way for the sinners in the modern city. Only in the mounting wail of sinfulness and cry for repentance can the Puritans purged themselves.

\section{The Ironic Representation of the Errand into the Wilderness}

In May 1670, Reverend Samuel Danforth delivered an election-day jeremiad entitled A Brief Recognition of New England's Errand into the Wilderness. The sermon is the community expression of a whole generation of the Puritan ministers. Though Danforth acknowledges the new promise land was far from won, he is still optimistic about the Puritans' errand. He compares the Puritans' migration to the American wilderness to Jews' exodus experience and praises the errand as "a migration from a soft civilization to the purity of the wilderness-condition" . (Bercovitch,1978, p.12) Compared with the Arabian desert of Moses, the American wilderness takes on the double significance of secular and sacred place. It witnesses the progress of New England's holy commonwealth and asserts the Puritans' destiny to usher in a new millennium.

By contrast with optimistic Danforth, Eliot feels pessimistic about the Puritan errand. In the satirical portrayal of Prufrock, the modern incarnation of John the Baptist, Eliot represents the Puritan errand ironically. Prufrock identifies himself with John the Baptist when he sees his "head (grown slightly bald) //brought in upon a platter" . (Eliot, 1969, p.15) In Mark, Herod married Herodias, his brother Philip's wife. John repeatedly told him it was not lawful to marry his brother's wife. Herodias nursed a grudge against John and wanted to kill him. On Herod's birthday banquet, 
Herodias' daughter danced and pleased Herod. Herod promised to give her whatever she wanted. The girl, to revenge for her mother, made the request: "I want the head of John the Baptist on a platter." Herod had to behead John. (Mark 6:17-25) Similar to John, Prufrock was a victim of women's persecution. "Pinned and wriggling on the wall", he was isolated and ridiculed by the women talking about "Michelangelo" and castrated by their "eyes" and "formulated phrase". (Eliot, 1969, p. 14)

According to Bercovitch, the figural use of John the Baptist is a characteristic of the New England pulpit, and part of the Puritan legacy to American rhetoric. (Bercovitch, 1978, p.13) The Puritan writers such as Samuel Danforth, Thomas Hooker, Edward Johnson, Increase Mather and Jonathan Edwards all interpret John as a typological forerunner of their own mission to prepare the way for Christ in the American wilderness. (Bercovitch, 1978, p.13) For example, Danforth says in the jeremiad: "John was greater than any of the prophets that were before him, the Baptist was the harbinger and forerunner. All the prophets saw Christ afar off, but the Baptist saw him present, baptized him, and applied the types to him personally." (Bercovitch, 1978, p.13) The Puritan typology explains the Puritans' preference to John. Typology is an ancient hermeneutic method which explicates signs in the Old Testament as foreshadowing events and people in the New Testament. For example, Jonah's three days in the whale typologically parallels Christ's three days in the tomb, and Job's patience prefigures Christ's forbearance on the cross. The New England Puritans develop this method into a distinctively American one. They believe all of history after the Incarnation foreshadows the Christ's second coming. Thus, as John the Baptist prefigures Christ, the Bay Colony is a light proclaiming the coming of the Messiah, a herald sent to prepare the world to receive the long-expected kingdom.

Different from John, Prufrock was a coward and could not undertake a prophet's duty. In the Biblical tradition, a prophet is an individual inspired by God through the Holy Spirit to deliver a message for a specific purpose. With a strong sense of morality, a prophet castigates the evil and corruption around him and is often the target of persecution and opposition. John shows great courage in condemning Herod's breaking of Mosaic laws. By contrast, Prufrock had no courage to "disturb the universe"(Eliot, 1969, p.14). He consoles himself:"There will be time, there will be time...// And time yet for a hundred indecisions, //And for a hundred visions and revisions,// Before the taking of a toast and tea."(Eliot, 1969,p.14) In the rite of Eucharist, "toast and tea”, as the symbol of Jesus' body and blood, foreshadows Jesus' crucification. "A hundred indecisions" before the Eucharist hint at Prufrock's hesitance to sacrifice. Prufrock recognizes his difference from John with his“ bold spot in the middle of the hair " (Eliot, 1969, p.14). In religious paintings, John has a thick hair. In the Bible, hair is the source of strength. Samson is strong because of his hair. When his hair is cut, he is as weak as others. (Judges 16:15) Prufrock's bald head indicates his lack of courage and strength. Prufrock at last becomes aware that "he was no prophet" and "here's no great matter". (Eliot, 1969,p.15) He is merely "an attended lord", "an easy tool" and "a fool". (Eliot, 1969,p.14)

\section{Eliot's Anxiety of American Identity}

The rhetoric of mission in the Puritan jeremiads shows the Puritans' anxiety of identity. Miller points out that a Puritan's "greatest difficulty would not be stones, storms and Indians, but the problem of his identity." (Miller 1956, p.11) According to Miller, the Puritans did not flee to America. They went there in order to work out the complete reformation which was not completed in England and Europe but which would be accomplished quickly if only the saints back there had a working model to guide them. (Miller,1956, p.11) After 1660s, with the collapse of Cromwell's Protectorate, the immigrants found themselves deserted. They had to turn inward to fill the venture with meaning by themselves and out of themselves. They devised the rhetoric of mission to confirm their identity: they were a company of Christians not only called but chosen as instruments of a sacred historical design. This unremitting anxiety of identity persist in American literature. Generations of Americans are haunted by the same question: "who are we?"

In the poem, Eliot's anxiety of identity is manifest in his ambivalent attitude towards the Puritan errand. On the one hand, influenced by his family's sense of mission, Eliot is haunted by images which remind him of the Puritan errand. William Greenleaf Eliot, Eliot's grandfather, migrated to St. Louis in wilderness in the 1830s and established the first Unitarian church of the city. For Eliot, William personifies the Puritan errand. Echoing the typological language of Puritan jeremiad, Eliot describes William as "a Moses bringing down the tables of the Law". (Eliot, 1964, p.44) On the other hand, by a satirical contrast between John and Prufrock, Eliot shows his doubt about the Puritan mission. Eliot indulges himself in an aesthetical world of sensual pleasure. "The mermaids" are "singing" and "riding seaward on the waves"; water was "white and black" and "sea-girls" were "wreathed with seaweed red and brown". (Eliot, 1969, p.16) In the pursuit of art, Eliot turns his back on the family obligation.

The poem can be considered an anti-jeremiad because of its ironic representation of the Puritan errand. The antijeremiad denounces all ideals, sacred and secular, on the grounds that America is a lie. (Bercovitch,1978, p.194) Antijeremiad is not a rejection but a variation of the symbol of America. The symbol of America is an enclosed and bipolar system.( Bercovitch,1978, p.178) America is represented as either "world's fairest hope or man's foulest crime, American heaven or universal hell”. (Bercovitch,1978, p.194) Locked within the bipolar structure, Jeremiad and antijeremiad are equal and opposite expressions of the same symbol. The symbol of America both sustains and restricts the imagination of Eliot. It sets free great creative energies of Eliot and becomes the source of his images, metaphors and symbols. Meanwhile, it confined Eliot's imagination to the terms of the American myth, barring him from paths that led beyond the boundaries of American culture. 


\section{Conclusion}

The Love Song of J. Alfred Prufrock shows the influence of the Puritan jeremiad tradition upon Eliot. Like a prophet howling in the American wilderness, Eliot is worried about the collapse of American ideals. His disquietude shows his deep identification with America. Different from the optimistic Puritan ancestors, Eliot is pessimistic about the Puritan errand. Although Eliot has doubt about the Puritan mission, he is always haunted by the images, metaphors and symbols traced back to the Bay Colony in the $17^{\text {th }}$ century. Eliot's literary imagination is sustained and restricted by the symbol of America and does not deviate from American culture.

\section{References}

Bercovitch,S. (1978). The American Jeremiad. Madison:University of Wisconsin Press.

Brooks, C. (1988). Teaching the Love Song of J. Alfred Prufrock. In J. S. Brooker (Ed.), Approaches to Teaching Eliot's Poetry and Plays. (pp.78-88) New York:The Modern Language Association of America.

Eliot, T.S. (1964). To Criticise the Critic and Other Writings. London: Faber and Faber.

Eliot, T.S. (1969). The Complete Poems and Plays of T.S.Eliot. London:Faber and Faber.

Elizabeth D. (1949). T.S.Eliot: the Design of His Poetry. New York:Charles Scribner's Sons.

Gordon,L.(1977). Eliot's Early Years. New York:The Noonday Press.

Miller, J. E.(2005). The Making of an American Poet.The Pennsylvania State University.

Miller,P. (1953).The New England Mind:From Colony to Province.Cambridge Massachusetts:Harvard University Press.

Miller,P.(1956). Errand into the Wilderness. Cambridge:The Belknap Press of Harvard University Press.

Pinkey.T.(1984). Women in the Poetry of T.S.Eliot: a Psychoanalytic Approach. London and Basingstoke: The Macmillan Press Ltd. 